\title{
La serie pietórica del Apóstol Santiago en el Templo Santiago Apóstol de Lampa-Pumo, de Isidoro Moncada
}

\author{
Flor Isabel Palomino Arana \\ Universidad Nacional Mayor de San Marcos \\ isabel_seth@hotmail.com
}

\section{Resumen}

Analiza la serie pictórica dedicada al apóstol Santiago, ubicada en el Templo Santiago Apóstol de Lampa, Puno, Perú. La serie es un conjunto de once pinturas atribuidas al artista cusqueño Isidoro Francisco Moncada, activo en la región del Collao durante la segunda mitad del siglo XVIII. Da a conocer una serie pictórica poco difundida y no estudiada, la que se aborda desde la perspectiva de la historia del arte, valiéndose de fuentes y herramientas de las disciplinas de la historia. El análisis se centra en los hallazgos de los grabados que sirvieron como fuente de inspiración al artista.

Palabras clave: Serie pictórica, Composición, Plano, Símbolo, Lienzo, Grabado

\begin{abstract}
Analyzes the pictorial series dedicated to the Apostle Santiago, located in the temple Santiago Apostle of Lampa, Puno, Peru. The series is a set of eleven paintings attributed to the artist Cusquenian Isidoro Francisco Moncada, active in the Collao region during the second half of the eighteenth century. It unveils a pictorial series little disseminated and not studied, which is addressed from the perspective of the history of art, using sources and tools of the disciplines of history. The analysis focuses on the findings of the engravings that served as a source of inspiration to the artist.
\end{abstract}

Keywords: Pictorial series, Composition, Plane, Symbol, Canvas, Engraving 


\section{La serie pictórica del Apóstol Santiago en el Templo Santiago Apóstol de Lampa-Puno, de Isidoro Moncada}

\section{Introducción}

El objeto de esta investigación es hacer un análisis pictórico de la quizá única serie dedicada al apóstol Santiago, en América, ubicada en la ciudad de Lampa, Puno. Es importante localizar y rescatar los grabados que sirvieron de inspiración al artista. Para tratar la figura de Santiago fue necesario abordar sus distintos cambios iconográficos; primeros, discípulo de Jesús; luego, peregrino; finalmente, santo ecuestre y guerrero a la cabeza de la reconquista de España y la conquista de América.

La serie objeto de estudio, ubicada en el altiplano, es la única del virreinato del Perú dedicada al apóstol Santiago, y quizá única en América. La preeminencia del santo ecuestre o peregrino no es casual, pues legitimó ideológicamente la conquista, y dentro del proceso de sincretismo religioso, ocupó en espacios más indígenas en el Cusco y el altiplano el lugar de Illapa, dios del trueno y del rayo, de raíces precolombinas y panandinas.

Este trabajo abre la puerta para continuar con otros estudios de las obras de Moncada, referidos a las magníficas iglesias de Orurillo y Azángaro. En la actualidad la serie en cuestión se encuentra en muy mal estado de conservación.

\section{Contexto histórico y social de la autoría de las pinturas}

El templo de Lampa fue mandado a erigir por el obispo Manuel Mollinedo y Angulo. Una losa tallada, ubicada a la izquierda de la fachada lateral izquierda, señala que su fabricación finalizó en 1683. El templo está compuesto por altos y anchos muros que forman la única nave de planta cruciforme; la parte alta de estos muros está decorada con la serie pictórica de Santiago Apóstol, serie atribuida al pintor cusqueño Isidoro Francisco Moncada; el conjunto de once pinturas de $3.50 \mathrm{~m}$ por $2.50 \mathrm{~m}$ aproximadamente, se encuentra distribuido por pares en la parte superior de 
las paredes laterales del templo. Dicha serie fue mandada a pintar por el párroco Bernardo López de Cangas.

Sobre la vida de este artista poco se conoce. Se detienen en él Teófilo Benavente (1995) y Teresa Gisbert (1982); esta estima que estuvo activo en la zona durante la segunda mitad del siglo XVIII y tuvo como modelo al pintor cusqueño Basilio Pacheco. El que Moncada firmara sus obras como "Maestro Mayor y Alcalde Veedor del Arte de la pintura de la gran ciudad del Cuzco" indica la importancia de su persona y sus obras.

\section{Apuntes hagiográficos}

El nombre de Santiago proviene del latín Jacobus. Para el interés de este trabajo es Santiago el Mayor, referido en los textos bíblicos. El dominico genovés fray Santiago de la Vorágine narra los sucesos supuestamente acontecidos luego de la Ascensión del Señor hasta la fecha de su presunto martirio, ocurrido según la tradición, un 25 de marzo, fecha similar a la Anunciación y Encarnación del Señor.

La adopción del santo se inicia después de su tránsito por España. Tomado por los españoles primero como peregrino, pasó a ser luego un feroz caballero matamoros durante la reconquista española, aspecto que se modificaría como mataindios durante la invasión a América, visto en algunas pinturas y esculturas.

Algunos cronistas en el Perú narran la presencia del santo ecuestre en el Sunturhuasi del Cusco, en 1536, pretendido suceso que dio lugar a un hecho sincrético porque los cusqueños sorprendidos se preguntaban "¿Quién es aquel Viracocha que tiene la Illapa en la mano?". ${ }^{1}$ De esta manera se originó un nuevo elemento iconográfico, que ya se revelaba en el Nuevo Testamento. El control del cielo y de las tempestades afirma el carácter guerrero. El cronista Bernabé Cobo relata que los incas imaginaron a Illapa como un hombre en el cielo formado de estrellas, con una maza en la mano izquierda y una honda en la derecha. El tirar la onda causaba los relámpagos y el estallido los truenos que a veces daba cuando quería que lloviese.

En la España del siglo XVI se creía que cuando había tempestad con truenos, era el caballo de Santiago que galopaba. Los soldados invocaban al apóstol antes de disparar sus mosquetes y arcabuces. Todo esto contribuyó al sincretismo de Santiago con Illapa. En la actualidad, Santiago continúa relacionado con las lluvias, la producción agrícola, y la ganadera.

1 Garcilaso de la Vega (1973, p.189). 


\section{Análisis de las pinturas de Isidoro Francisco Moncada en Lampa}

Para la serie de once lienzos, el artista investigó acerca de la supuesta vida del santo para poder plasmar las escenas que consideró las más representativas.

Isidoro Francisco Moncada incluye en la serie de la iglesia de Lampa, seis pasajes vinculados al Evangelio, uno de Hechos de los Apóstoles, y cuatro de la hagiografía del santo. Para este artículo se tratarán seis pinturas que se han inspirado en grabados holandeses. Tenemos lo siguiente: Transfiguración en el Monte Tabor, Curación de la bija de Jairo, Petición de la madre de los hijos de Zebedeo, Virgen del Pilar, Batalla de Clavijo, Traslación de los restos de Santiago el Mayor.

El fenómeno que relaciona al grabado con la pintura va más allá de la similitud formal. La importancia está en el proceso mismo de creación plástica, es decir en los mecanismos por los que nuestros pintores descubrieron, asimilaron y se apropiaron de esquemas de composición para ilustrar conceptos iconográficos de profundo significado para la mentalidad virreinal.

\section{Transfiguración en el Monte Tabor}

La transfiguración es narrada en los evangelios de San Mateo y San Marcos (9: 2-7). La obra fue inspirada del grabado de Hieronymous Wierix (1533-1619), ${ }^{2}$ es una copia fiel en su composición. El grabado señala a Pedro, Santiago y Juan como testigos del episodio. Mientras Jesús, en medio de Elías y Moisés, es llamado por el Padre Celestial, los apóstoles, a sus pies, son envueltos por una nube.

$\mathrm{El}$ artista recorta dos pequeños cuadros al fondo inferior derecho del grabado, y no incluye el título ni la leyenda descriptiva, escritos en latín. Pero gracias a esta cartela es posible identificar la ubicación de las imágenes participantes de la transfiguración.

La pintura, de estilo barroco, tiene un lenguaje plano. El fondo lo compone un rompimiento de gloria compuesto por nubes y querubines; la disposición de las imágenes mantiene una jerarquización de los poderes religiosos. En la parte superior, Dios Padre, con los brazos extendidos rodeado de querubines, ataviado con hábito azul y capa roja. Esta composición revela la transformación de la divinidad, exaltando la belleza espiritual de Jesús como figura central.

En la parte superior izquierda Moisés y a la derecha Elías; en el lado inferior izquierdo, Juan y Pedro, y en el derecho el apóstol Santiago el Mayor. Las figuras apostólicas parecen flotar en el aire mientras son envueltas por nubes que cubren

2 Hieronymous Wierix (1533-1619) fue miembro de una dinastía de grabadores flamencos, estuvo al servicio de los Jesuitas y tuvo una enorme acogida en el arte americano. De Amberes al Cusco (2009, p. 28). 


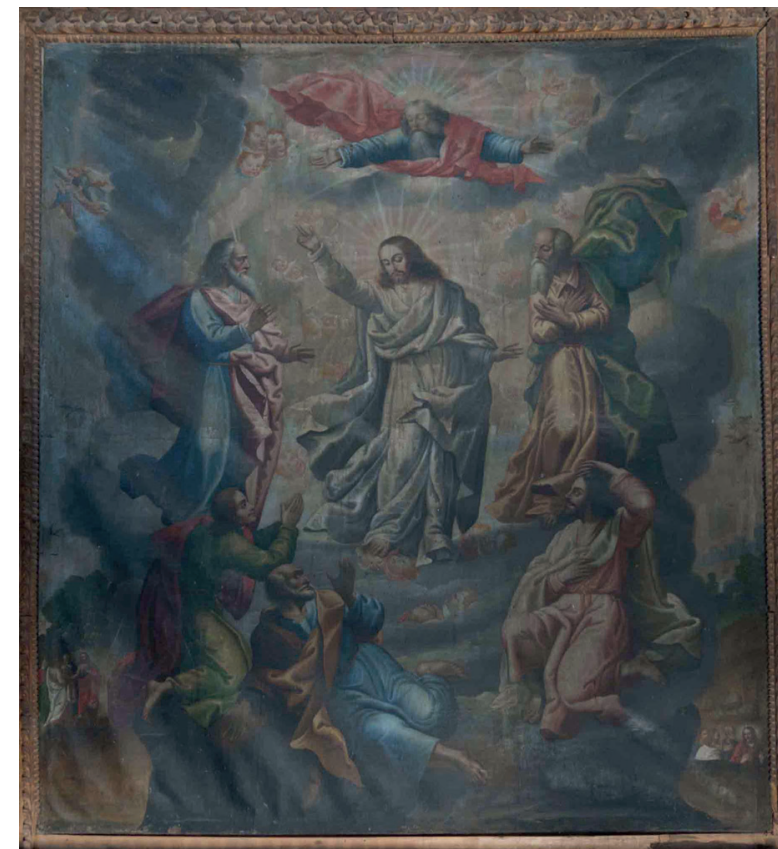

Fig. 1. Transfiguración en el Monte Tabor, Serie Santiago apóstol del Templo de Lampa.

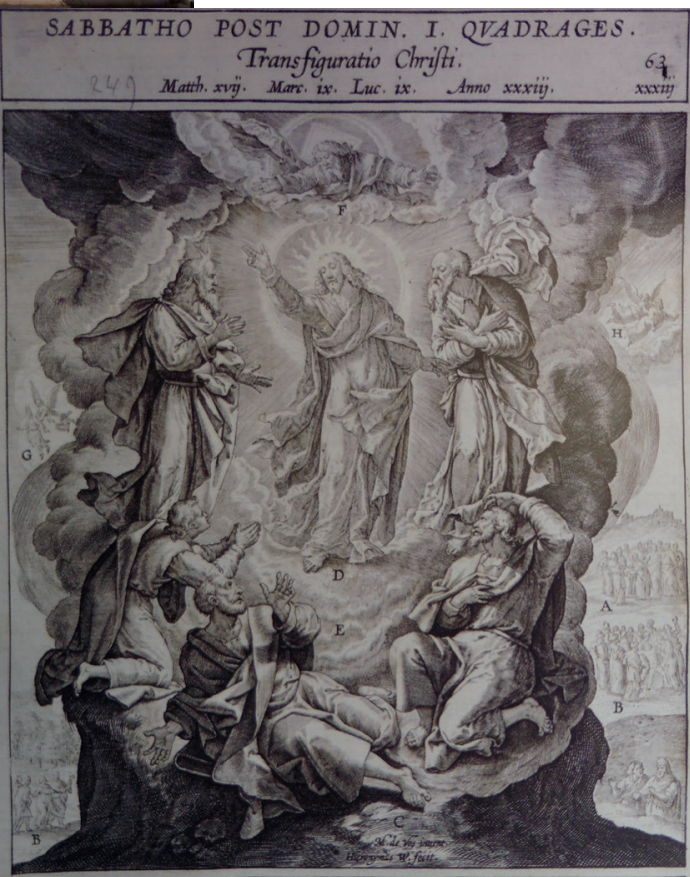

Fig. 2. Hieronymus Wierix, Transfguración en el Monte Tabor. \begin{tabular}{|l|l|l|}
\hline A. Paneas regio, vnde IESVS in Thabor & E. Euigilantes quafi e fommo discipuli, vi
\end{tabular} montem proficicictur.

melictis alys difcurulis ad nadices mon: tis cum turba, Petrum, Iacobum, o Ioamem fecum in caciumen aßumpsit.

C. Thabor in campo magno Gahleca Esarcion.
D. IESVS in plaracie montis, curus radumdat gloria anmie in corpus, quir fuit trant gloria anamie in corpus, que fuit trany
fyaratio. Adfunt Moyses, O' Elias. lent IESVM transfiguratum; 0 Petrus ait; Bormum of nes hic offe, of F. Adhuc eo loquente, ecce, nubes obumbra unt cos; Of fut vox Patris e collo, Oै. Morses in Lmburm .

H. Elias in paradisam terreftrem raptus, cum Atos toli ad vocem cecidiffent in terram

Dominica iै Quadragduma, idem Enangelum legitur. 
todo el acontecimiento sobrenatural. Moisés, Elías y Juan mantienen las manos en posición orante como símbolo del alma libre de las ataduras del cuerpo; también significa la unión del alma, mente y sentimiento con lo divino. Las posturas de Santiago y Pedro indican temor e impresión. A ambos lados del fondo inferior escenas que representan el trayecto que Jesús hizo con estos discípulos camino al monte Tabor.

El pintor propone una mayor carga cromática al lado izquierdo, en el que resaltan los colores fríos como el verde y el azul. Al lado derecho los colores son más discretos y cálidos. Tanto el grabado como la pintura son fieles al relato bíblico, destacan las actitudes de piedad y temor a Dios.

\section{Curación de la hija de Jairo}

Este tema está descrito en los Evangelios de Mateo (9: 18-26) y Marcos (5: 21-43). El asunto principal del óleo de Moncada ha sido tomado de la parte central del grabado de Anton Wierix, de Amberes (Bélgica), de fines del siglo XVI. En la lámina de Wierix se relatan dos milagros de Cristo acaecidos el mismo día: la curación de la mujer hemorroisa, en tres pequeñas y secundarias secuencias colocadas a la izquierda de la composición; y la resurrección de la hija de Jairo, tema principal de la obra.

La obra de Moncada, inspirada en el citado grabado, está estructurada en dos ambientes, uno externo, que relata entre otros asuntos, el milagro de la mujer hemorroisa, y el tema principal, la curación de la hija de Jairo, desarrollado en el

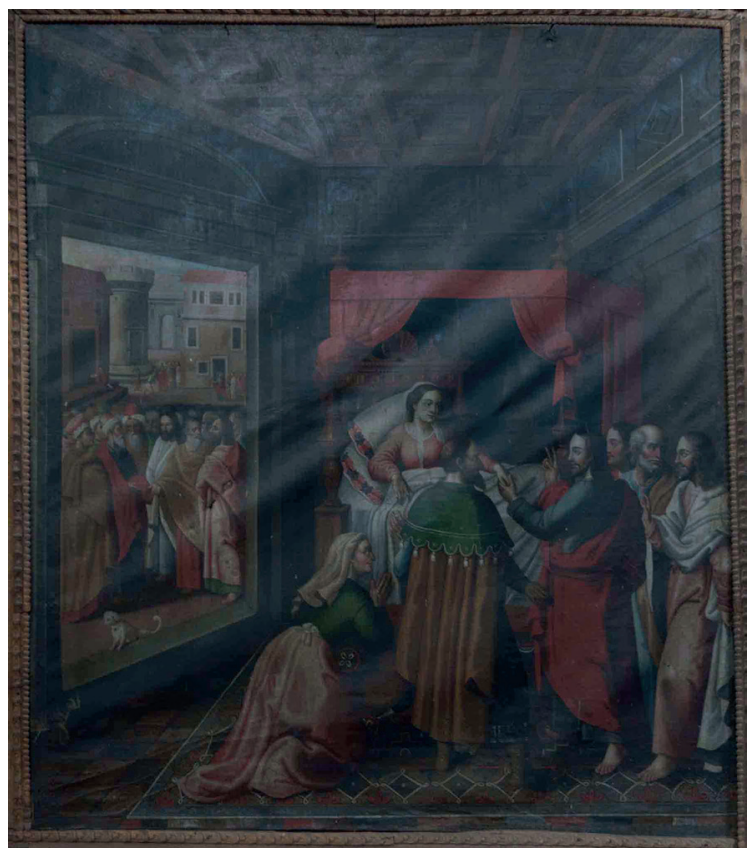

Fig. 3. Curación de la bija de Jairo, Serie Santiago apóstol del Templo de Lampa 
interior de una rica habitación. Con pequeñas variantes, esta escena es la misma que la propuesta por Wierix. Moncada se toma la libertad de modificar el lecho al plantear un dosel plano frente al cónico. A esto se suma la solución del techo a través de casetones.

Sobre la mano izquierda del óleo, Moncada presenta un segundo plano, se trata de un espacio abierto al que se accede a través del umbral de la puerta. El artista narra, en el primer plano y de mayor envergadura, la llegada del Maestro a la casa de Jairo. En esta escena es difícil diferenciar a Jesús y a Santiago, por haber la variación cromática de sus indumentarias. En este espacio el artista añade la figura de un pequeño perro blanco. En la parte superior de este sector, al igual que Wierix, el artista cusqueño relata el ya citado pasaje de la mujer hemorroisa.

Para relatar este episodio Moncada lo hace en dos pequeñas escenas empleando como fondo una ciudad de características renacentistas.

Fig. 4. Antón Wierix, Curación de la hija de Jairo.

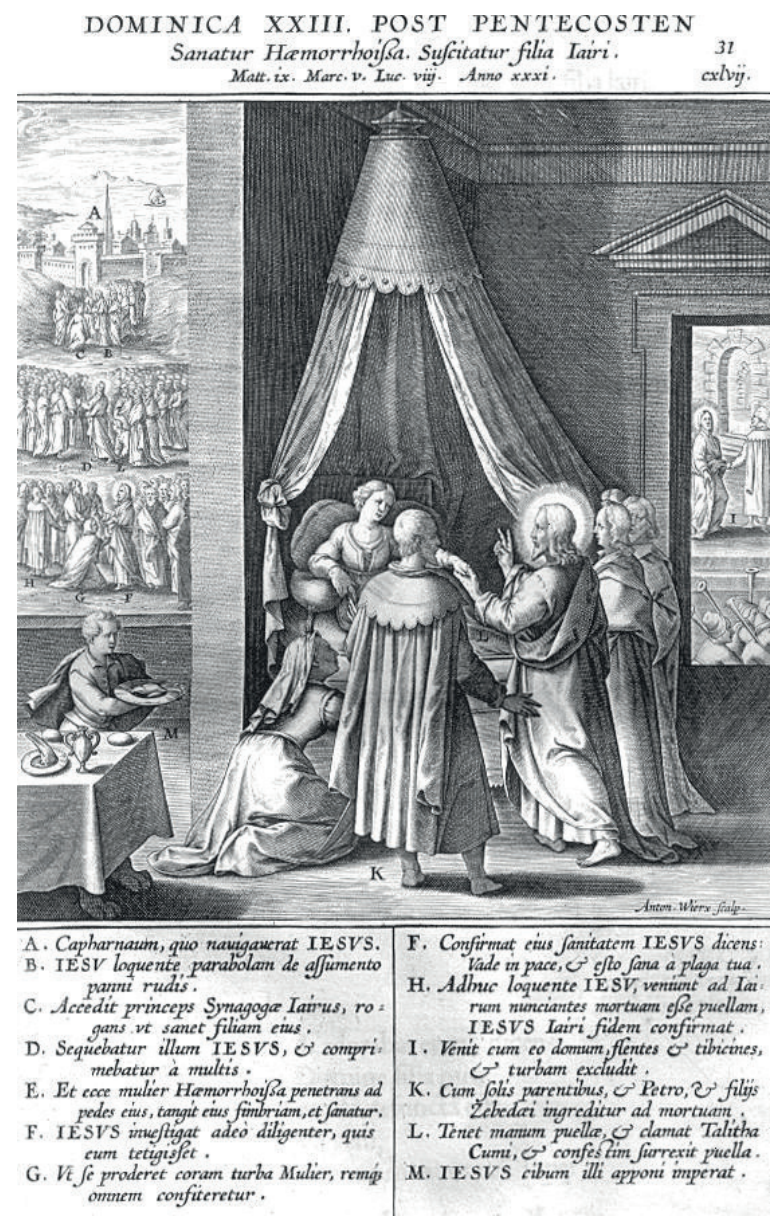




\section{Petición de la madre de los hijos de Zebedeo}

Este pasaje bíblico está descrito en el evangelio de Mateo (20: 20-24). El óleo está inspirado en el grabado Jesús entre los doctores, del ya citado Hieronymous Wierix, que cuenta una de las primeras manifestaciones de Jesús niño (Lc 2: 41-50); en la parte baja se lee el listado de ocho ítems escrito con mayúsculas, el cual describe cada escena. El grabado de Wierix fue adaptado por Moncada para representar a Santiago y Juan como protagonistas.

El esquema compositivo de la pintura se desarrolla alrededor del trono donde dos peldaños más abajo, dos sillones rojos vacíos están a la espera de ser llenados, muebles reclamados por la madre de Santiago y Juan para sus hijos. A través del trono de madera tallado y rematado con una venera, Moncada podría relacionar la madera con el oficio de carpintero que Cristo aprendió de su padre y la venera como peregrino durante los años de la vida pública de Santiago.

Jesús, de túnica verde y manto rojo, señala con la mano derecha el cáliz que sostiene con la izquierda, tal vez como alusión a su próximo sacrifico. Se encuentra al medio de una escenografía barroca sostenida por columnas pareadas helicoidales.

En el plano inferior, separado por tres peldaños altos en cuyas huellas Moncada hace un derroche de rosas rojas en su mayoría y blancas, las primeras aluden

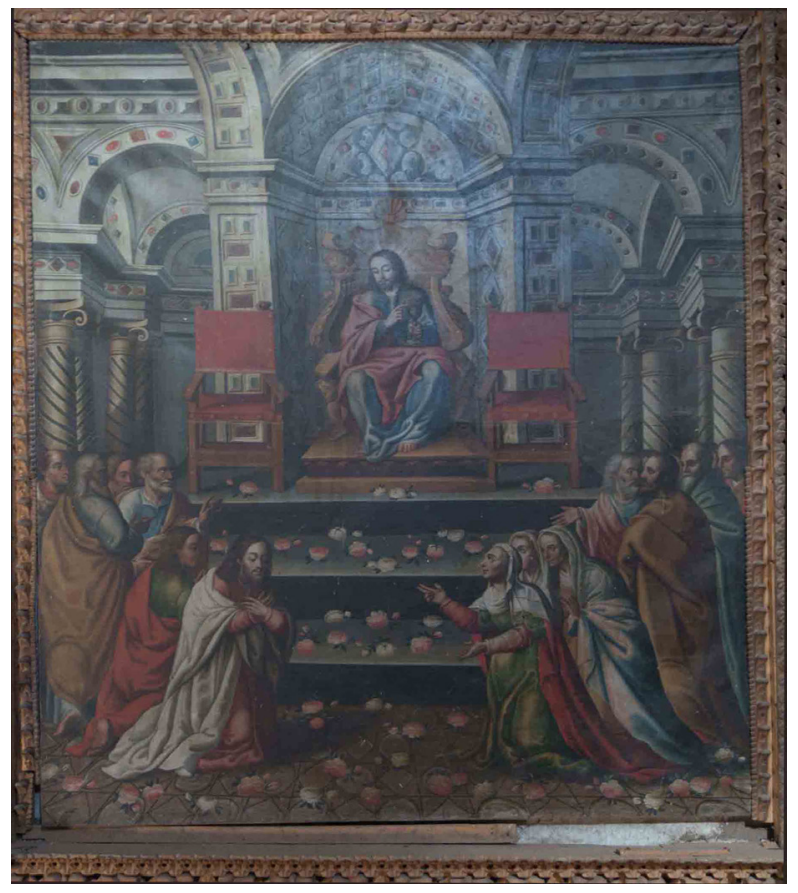

Fig. 5. Petición de la madre de los bijos de Zebedeo. Serie Santiago apóstol del Templo de Lampa. 
Fig. 6. Hieronymus Wierix, Jesús entre los doctores.

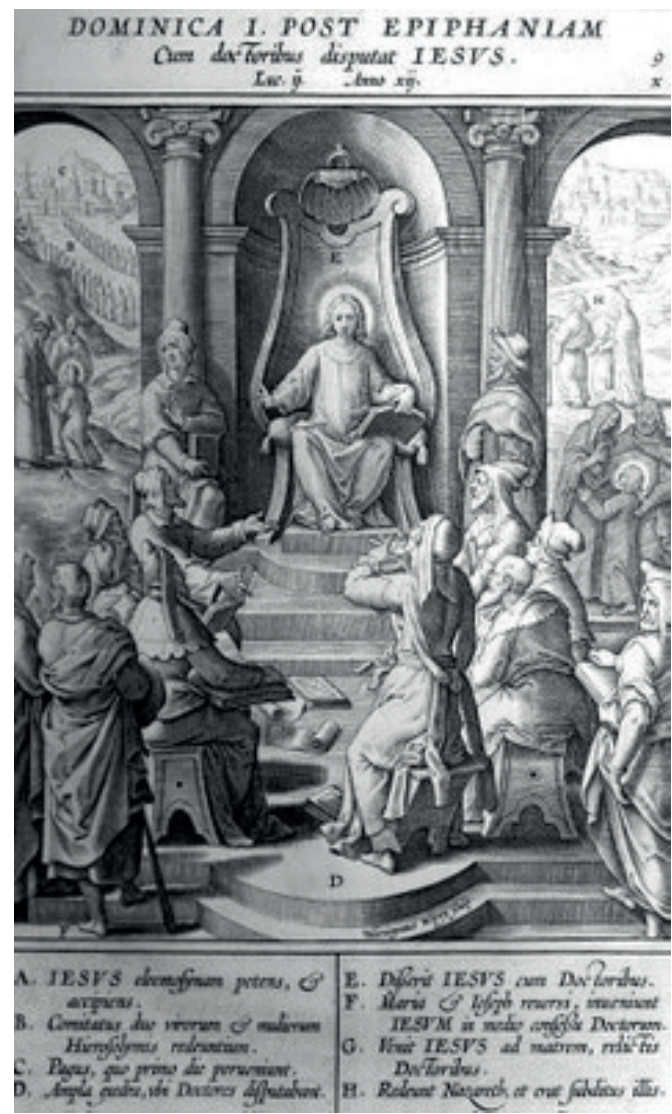

al martirio de Cristo y las blancas a la pureza mariana, ${ }^{3}$ seis apóstoles se ubican a cada lado de la escalera. Hincados, al lado izquierdo, Santiago y Juan; de pie San Pedro y otros. Frente a los hermanos, su madre de rodillas, acompañada de otras dos mujeres, solicita al Maestro que ocupen los sillones rojos vacíos.

Siguiendo el relato de Mateo en el cual señala que los otros diez apóstoles "se indignaron contra los dos hermanos", Moncada los representa de pie, tanto a la izquierda como a la derecha, mientras gesticulan de manera airada.

\section{Virgen del Pilar}

La estampa que inspiró a Isidoro Moncada para este cuadro data de 1610, obra del grabador español Diego de Astor (1588-1637). En 1610 grabó la portada del libro de Mauro Castella Ferrer, Historia del apóstol de Jesucristo Santiago, además del retrato del autor y algunas estampas. ${ }^{4}$

3 Leonardini (1996, p.219).

4 Franco Mata (2011, p.205). 
En Virgen del Pilar, Astor presenta al centro a la Madre de Cristo en una mandorla, de pie sobre un pilar, rodeada por un querubín a cada lado y un par de ángeles músicos: un arpista y un laudista. En la parte baja Santiago y sus discípulos de rodillas, contemplan absortos a la Virgen. Lo ya descrito está rodeado por diecisiete escenas que relatan la labor de evangelización realizada por el apóstol en España.

Moncada simplifica la composición del grabado al retirar las diecisiete escenas comentadas; asimismo, cambia la ciudad por un paisaje natural y a Santiago y sus apóstoles les da personalidad al diferenciar a cada uno de ellos.

Este óleo, estructurado en torno a una vertical representada por la Virgen del Pilar, está dividido en dos planos: mundo terrenal y mundo celestial.

En el plano superior un rompimiento de gloria; en él la Virgen al medio está rodeada por una resplandeciente aureola solar y un halo de nubes. Ataviada con túnica rosa y manto azul en movimiento, la imagen se encuentra rodeada por ocho ángeles músicos, y cabezas de querubines dispuestos en pares.

En el plano inferior la escena se divide por el pilar de mármol; la columna está decorada en el fuste con la cruz de Malta y rombos en cuyos centros hay incrustaciones de rubíes, diamantes y esmeraldas.

A ambos lados del pilar están Santiago y sus discípulos hincados, en actitud contemplativa. Al lado izquierdo Santiago con fino halo, precede a un grupo de

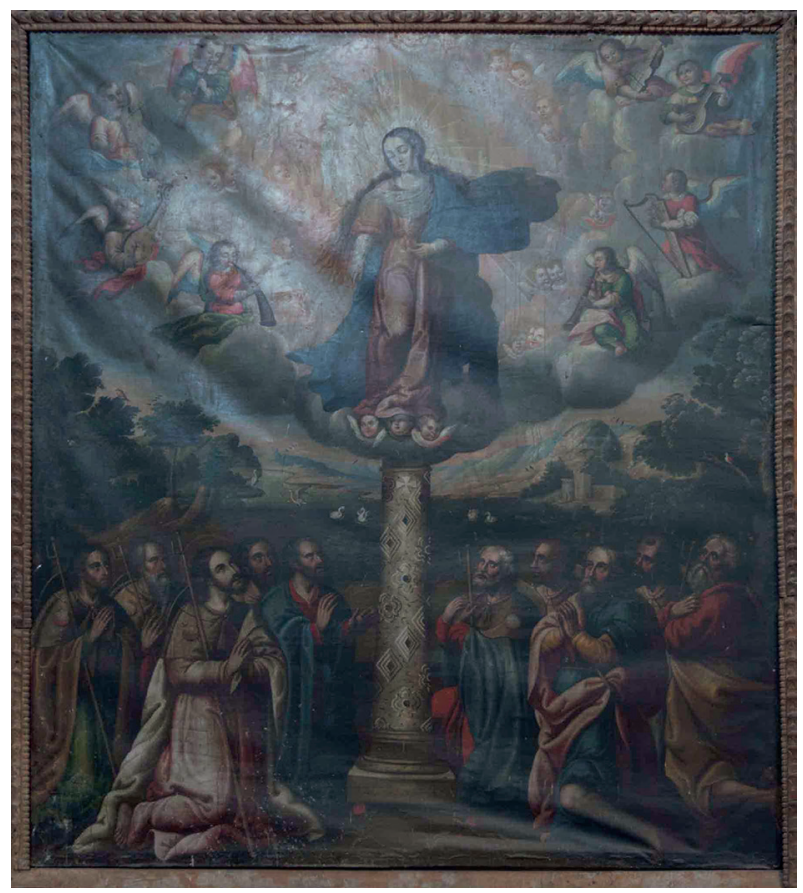

Fig. 7. Virgen del Pilar, Serie Santiago apóstol del Templo de Lampa 
Fig. 8. Diego de Astor, La llamada de San Santiago

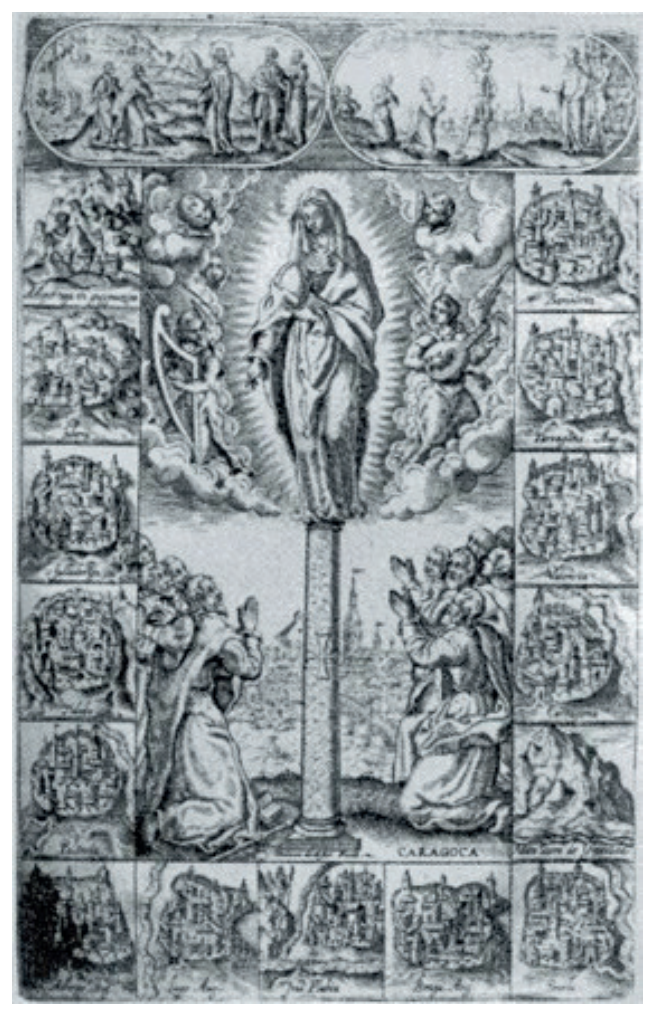

cuatro. A la derecha y en la misma posición se encuentran los otros cinco personajes, donde uno de ellos igualmente precede a los otros cuatro.

Los colores rojo y azul armonizan el conjunto, matices cafés, y toques de tonalidades cálidas.

El fondo está compuesto por un paisaje bucólico, rodeado de árboles con pajarillos, montañas, una pequeña fortificación con dos torres y una laguna con cisnes, uno de ellos alzando el vuelo. Una bandada de aves adorna el cielo.

En esta composición se identifica un orden jerárquico religioso, relacionado con los personajes y símbolos iconográficos.

\section{Batalla de Clavijo}

La representación como matamoros se popularizó a partir del siglo XVI. Iconográficamente tuvo mayor relevancia ya que, según la leyenda, fue bajo su protección como España logró reconquistar su territorio después de ocho siglos de dominio islámico. Convertido el santo en símbolo de la reconquista, los españoles iniciaron la empresa de la conquista en América, generalmente invocándolo en cada enfrentamiento contra los aborígenes. 
El grabado anónimo que inspiró a Moncada en el siglo XVIII para elaborar el lienzo Batalla de Clavijo, presenta un formato rectangular en una composición que gira en torno al santo. Las líneas verticales, horizontales y diagonales están presentes en todo el conjunto visualizadas en las lanzas y figuras humanas.

El grabado está organizado en dos planos; el primero ocupa el centro de la composición; en esta sección el grabador amplió las imágenes de los moros para guardar armonía con el tamaño del santo ecuestre; su corcel está cubierto por una gualdrapa decorada con cruces rodeadas de veneras. Santiago, con túnica y capa volante con veneras; porta sombrero de peregrino y espada desenvainada. Su cabeza está envuelta en un halo solar.

El segundo plano muestra el enfrentamiento entre las huestes españolas, y las moras, simbolizadas por la infantería en clara huida.

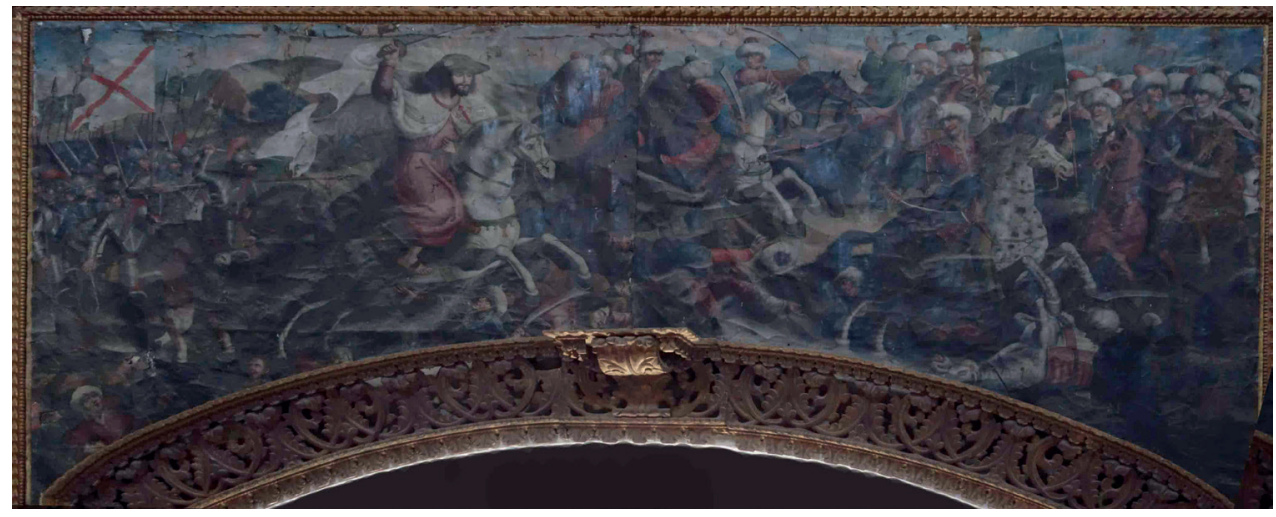

Fig. 9. Batalla de Clavijo, Serie Santiago apóstol del Templo de Lampa

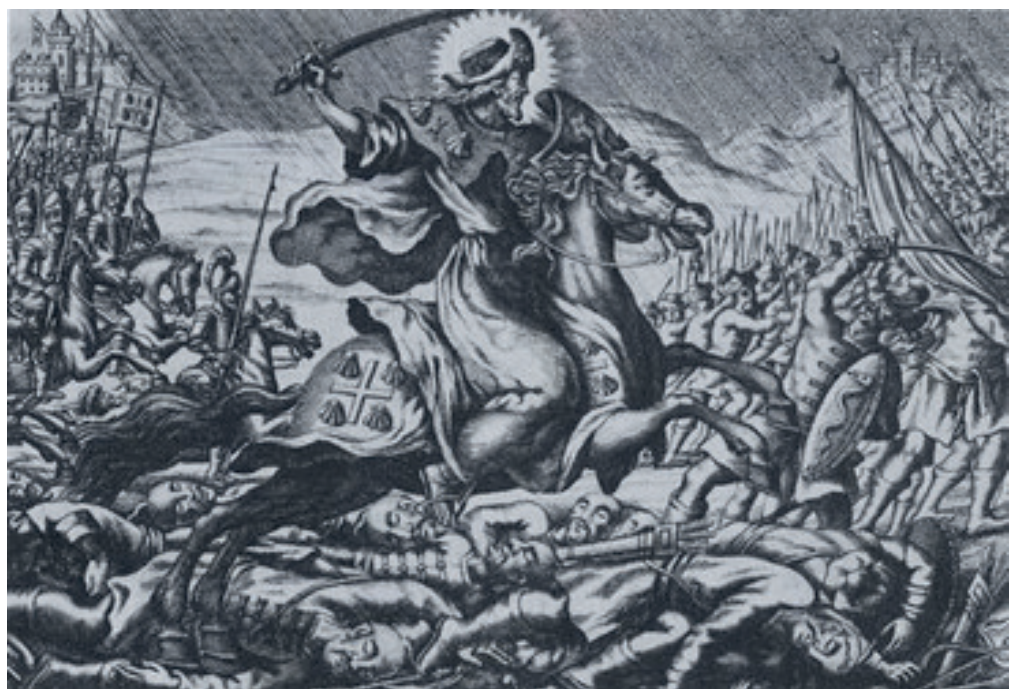

Fig. 10. Grabado anónimo, Santiago en la batalla de Clavijo 
La imagen del Matamoros ejecutada por Isidoro Moncada presenta una composición apaisada donde el ancho es casi tres veces la medida del alto; el artista mantiene una escena similar a la del grabado, pero modifica los espacios y la composición en tres planos. En el primero el santo ecuestre, descalzo, parece volar sobre una ola de cadáveres; porta espada desenvainada y muestra su preeminencia y poder liderando el ejército español. Viste con los atributos del peregrino: sombrero con venera y capa con la cruz de Santiago. En este sector el artista desplaza y reduce el tamaño de la imagen del santo, con respecto a la del grabado. El segundo plano está compuesto por las huestes moras divididas en dos grupos; el primero se enfrenta al santo, el segundo, ubicado en el lado derecho de la tela, soldados quienes parecen emprender la retirada.

El tercer plano, en el ángulo izquierdo superior del óleo, la caballería española con armaduras, cascos y espadas desenvainadas; uno de ellos lleva desplegada la bandera blanca con una cruz roja en aspa, emblema utilizado desde el siglo XVI en los escudos y banderas de las fuerzas españolas. ${ }^{5}$ La composición se desarrolla en un campo de batalla sugerido por la polvareda levantada, bajo una alfombra de cadáveres moros.

Este lienzo representa al apóstol con doble iconografía: como peregrino con los aditamentos del sombrero, la capa, el hábito y la concha, además de estar descalzo. Como ecuestre, muestra su carácter belicoso al levantar la espada desenvainada, cortar cabezas y pisar al enemigo. De esta manera, al mensaje cristiano se suman otros de carácter ideológico y político, características que encajaban en los propósitos de las campañas de los españoles.

\section{Traslado de los restos de Santiago Apóstol}

Isidoro Moncada estructuró el cuadro en tres planos. El tercero ocupa el tercio superior del lienzo y configura el fondo de la obra. Allí se inicia la historia, cuando después de degollado el santo, un 25 de marzo, por orden de Herodes Agripa, sus discípulos lo recogieron poniéndole en una nave sin timón, conducida por un ángel que lo llevó hasta las costas de Galicia.

Moncada pinta una suntuosa embarcación en forma de bóveda de cañón corrido silueteada de dorado que navega apaciblemente; aves en el cielo. El acontecimiento milagroso está rodeado de montañas bajas, nubes blancas y negras.

En el segundo plano se relata la llegada de los restos a las costas de Galicia. Esta zona ha sido trabajada de manera irregular, pues las dos terceras partes del lado derecho del cuadro invaden al tercer plano con un paisaje urbano. El primero

5 El pendón de Santiago representaría la reivindicación triunfal de Santiago, que los burgueses compostelanos quisieron sustituir por el realengo de Castilla. Sebastián (1993, p.283). 


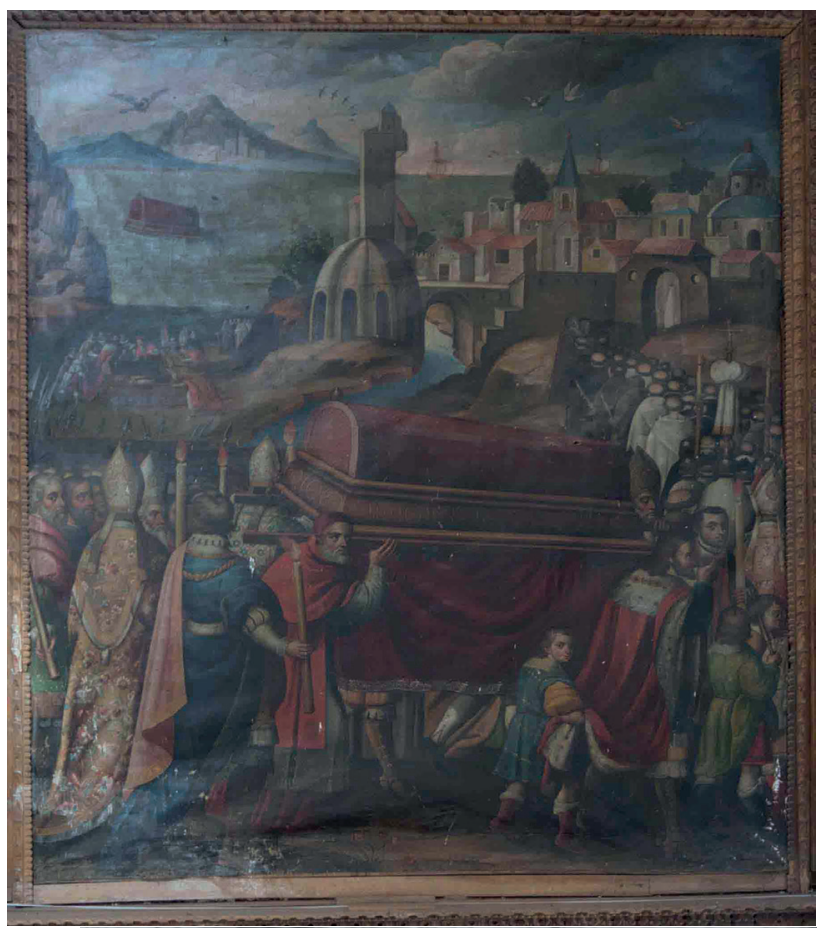

Fig. 11. Traslado de los restos de Santiago, Serie Santiago apóstol del Templo de Lampa.

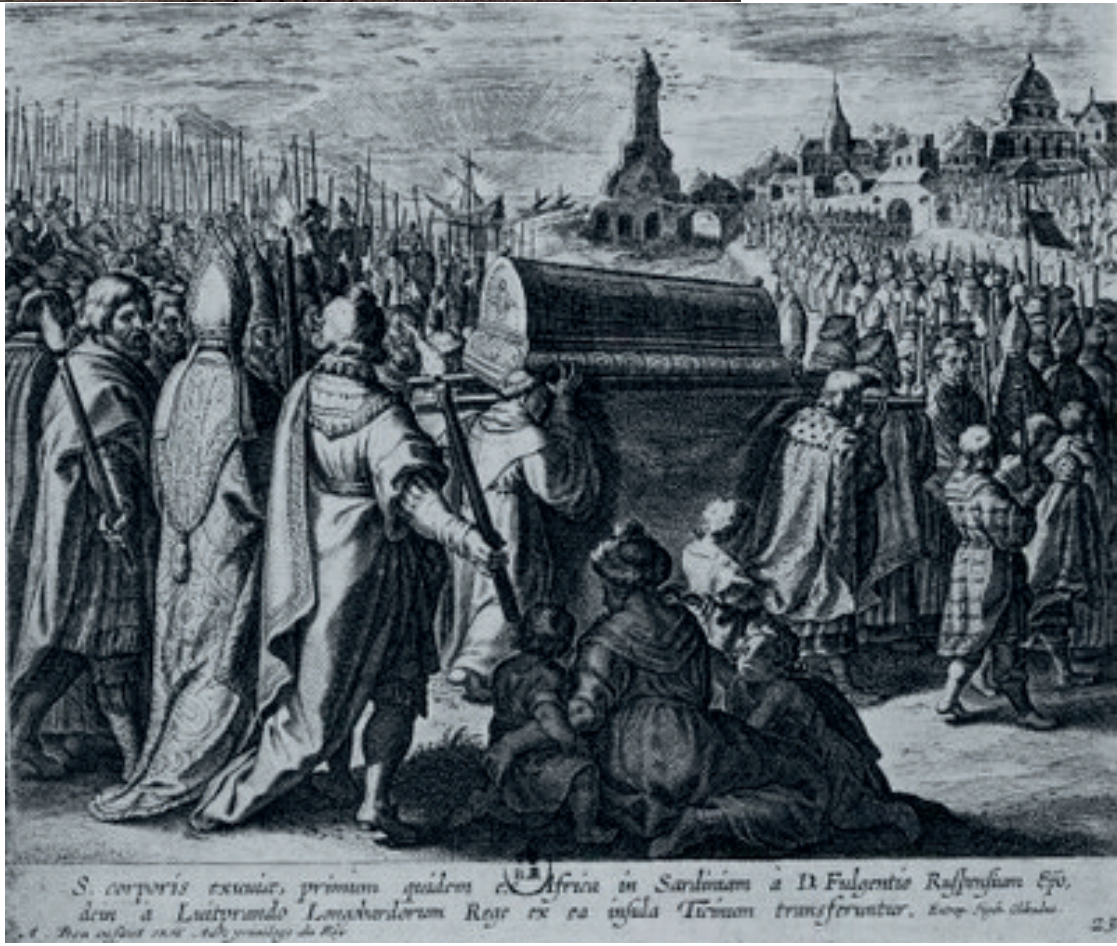

Fig. 12. Shelte a` Bolswert \& Cornelis Galle, Traslación de los restos de San Agustín 
y segundo plano ocupa la mitad del lienzo, espacio en el cual Moncada se expresó plásticamente con gran libertad en cada uno de los detalles.

En este plano, un grupo de religiosos esperan y luego reciben, a la orilla del mar, los restos del santo. El relato continúa con otro grupo que lo lleva a tierra firme para, posteriormente, abrir el féretro por dos sacerdotes de alto rango, en cuyo interior se halla el cuerpo del apóstol ataviado de blanco, con la cabeza rodeada de un resplandeciente halo de luz. A la mano derecha de estas escenas se perfila una interesante ciudad amurallada; por la puerta de la ciudad entra una procesión eclesiástica con personajes vestidos con rico ajuar litúrgico.

El primer plano, es decir la mitad del lienzo, resulta ser el más importante de la obra. Es inspiración del grabado de la serie Agustiniana de Bolswert y Galle ${ }^{6}$ al que mutiló. El grabado original, concebido en formato horizontal, al trasladarlo al lienzo se torna vertical. Moncada lo recorta en los extremos por motivos de espacio, razón por la cual varios personajes secundarios fueron eliminados.

Acá se escenifica el traslado de los restos de Santiago desde Jerusalén hasta Compostela. El féretro cargado es llevado en procesión.

El fuego de los largos cirios cargados por algunos personajes, simbolizan la inmortalidad divina del espíritu, ${ }^{7}$ en este caso del apóstol Santiago.

\section{Conclusiones}

Esta serie hasta donde se ha investigado es la única en todo el arte americano, dedicada al apóstol Santiago el Mayor. Moncada, al igual que otros pintores cusqueños, por lo general decora sus paisajes con coloridas aves, característica de la pintura cusqueña del siglo XVIII, es decir de su propia época. En la serie estudiada, el rojo tiene predomino. Esto podría responder a Moncada como pintor cusqueño, porque es sabido que en la pintura virreinal de esta región dicho color es uno de los más empleados.

En toda la serie, el artista interpretó la vida y milagros de Santiago basado siempre en las versiones de la Iglesia Católica, o tradiciones europeas. A pesar de ser un artista cusqueño nunca dejó escapar las creencias andinas o elementos amestizados o sincretizados. Entonces, si hay algo a lo que pueda llamarse mestizaje, aquí no hay mestizaje. Esto se confirma con los seis grabados holandeses ubicados y que tal vez fueron proporcionados por el vicario Bernardo López de Cangas, quien mandó pintar la serie.

6 Bolswert fue uno de los más distinguidos miembros de la escuela de grabadores de Amberes. En este mismo lugar en 1624 apareció una serie de veintiocho grabados sobre la vida de San Agustín. PESSCA: 268A/305B. Recuperado de http://colonialart.org/galleries/2\#c268a-305b

7 Cirlot (2011, p. 461). 
Moncada muchas veces realiza cambios cromáticos en los atuendos de los personajes, lo que provoca confusiones al espectador en la lectura del cuadro. Luego, como elemento compositivo, el artista utiliza constantemente líneas verticales, horizontales y diagonales, visualizadas de manera permanente en troncos de árboles, figuras humanas, inmuebles y lanzas.

Moncada se inspiró y reinterpretó; no hizo copia fiel de los grabados; se tomó la libertad de recortar, modificar y añadir nuevos elementos en su composición.

Isidoro Moncada lo entendió como un proyecto, conocía el templo y su disposición es orgánica: Las pinturas tienen las mismas dimensiones, a excepción de la $\mathrm{Ba}$ talla de Clavijo, adecuada a la parte superior del vano de la puerta lateral del templo.

\section{Referencias}

Benavente, Teófilo (1995). Pintores Cusqueños de la Colonia. Cusco: Municipalidad del Qosqo.

La Biblia (1982). Barcelona: Herder Editorial.

Cirlot, Juan Eduardo (2001). Diccionario de Simbolos. Madrid: Siruela Editorial.

Cécile Michaud; Almerindo Ojeda Di Ninno; Luis Eduardo Wuffarden; Luisa Fiocco Bloisa; Jaime Mariazza Foy; et al. (2009). De Amberes al Cusco. El grabado europeo como fuente del arte virreinal. Colección Barbosa-Stern. Lima: Impulso Empresa de Servicios SAC,

De La Vorágine, Santiago (1990). La leyenda dorada. Madrid: Alianza.

De La Vega, Inca Garcilaso (1973). Comentarios Reales de los Incas. Lima: Peisa.

Leonardini, Nanda y Borda Patricia (1996). Diccionario iconográfico religioso peruano. Lima: Rubican Editores.

Franco Mata, María Ángela (2011). Ana María Roteta de la Maza. In memorian. Anuario del Departamento de Historia y Teoría del Arte, vol. 23, 205-206.Universidad Autónoma de Madrid.

Mesa, José de y Gisbert, Teresa (1982). Historia de la pintura cusqueña. Lima: Fundación Augusto N. Wiese.

Pessca. Proyect on the Engraved Sources of Spanish Colonial Art. Recuperado de http://colonialart.org/archives [Consulta: 16 de enero del 2015, 11:00 horas]

Sebastián, Santiago (1993). La iconografía de Santiago en el arte hispanoamericano. En Santiago y América, Xunta de Galicia Consellería de Cultura e Xuventude. (pp.276-288). Santiago de Compostela: Arcebispado de Santiago de Compostela. 